\title{
Soil and Vegetation Responses to Simulated Trampling
}

\author{
AHMED H. ABDEL-MAGID, M.J. TRLICA, AND RICHARD H. HART
}

\section{Abstract}

An artificial hoof was used to simulate trampling effects on native shortgrass sods in a greenhouse experiment. Severe to moderate trampling was applied to sods maintained under 3 soil water regimes. Trampling was done either throughout a 32-day period to represent a continuous grazing system, or only during the last 4 of the 32 days to simulate a short-duration grazing system. Soil bulk density increased $3 \%$, and infiltration rate declined $57 \%$ under severe trampling. Trampling throughout the 32-day period resulted in $4 \%$ higher bulk density than did a similar level of trampling that was applied only during the last 4 days of the trial. Dead vegetation was more easily removed by hoof action than was living vegetation, and severe water stress made plant material more brittle. Aboveground biomass production was $7 \%$ greater under trampling that simulated short-duration graxing, and $17 \%$ more forage remained in the standing crop under this treatment. About $38 \%$ more vegetation was detached by hoof action under simulated continuous grazing as compared with the short-duration grazing treatment.

Key Words: treading, compaction, infiltration, herbage loss, soil water, trampling

Livestock trampling has both direct and indirect effects on vegetation and soils. There are physical effects of the grazing animals' hoof action which can cause mechanical injury or loss of vegetation standing crop, as well as compaction of the surface soil by the pressure exerted by the hooves (Dadkhah and Gifford 1980, Lewis 1980, Packer 1953, Balph and Malechek 1985). Brown and Evans (1973) stated that the key factor in pasture damage was the amount of animal walking (treading). Therefore, any factor that reduces walking (e.g., distance to water, forage availability, etc.) should reduce pasture damage. Several studies have attempted to estimate the amount of forage lost by trampling under field conditions (Laycock et al. 1972, Laycock and Harniss 1974, Quinn and Hervey 1970, Pearson 1974, 1975). However, little information is available to elucidate differences in forage loss between uncontrolled and controlled grazing (Holechek 1980), so most estimates of forage loss are based on several assumptions such as distance traveled, animal selectivity, and other behavioral and measurement biases.

Lull (1959) reported that cattle exerted static or standing loads (averaged over the entire surface area of the hoof) of $10.9 \mathrm{~kg} \mathrm{~cm}^{-2}$. However, 2 to 4 times the static load can occur when an animal travels. Dadkhah and Gifford (1980) and Busby and Gifford (1981) used a static loading of $13.6 \mathrm{~kg} \mathrm{~cm}^{-2}$ in their artificial trampling studies. Frame (1971) indicated that cattle with a hoof print size of 60 to $90 \mathrm{~cm}^{2}$ exerted 2.8 to $4.2 \mathrm{~kg} \mathrm{~cm}^{-2}$ pressure on the soil surface while traveling. Static load can be calculated simply as the total weight of the animal divided by total surface area of the bottom of its 4 hooves. A $400-\mathrm{kg}$ steer, with each hoof having a surface area of $80 \mathrm{~cm}^{2}$, would exert a static load of $1.25 \mathrm{~kg} \mathrm{~cm}^{-2}$, and a load while traveling of 2.5 to $5.0 \mathrm{~kg} \mathrm{~cm}^{-2}$. This load would vary according to

\footnotetext{
Authors are graduate research associate and professor, Range Science Department, Colorado State University, Fort Collins 80523; and range scientist, USDA/ARS, High Plains Grassland Research Station, Cheyenne, Wyo. 82009.

We wish to thank Paul Brown of the USDA/ARS for his field assistance. We also thank James W. Knadler, Art Department, University of Wyoming, for casting the bronze hoof used in this study. The reviews and suggestions for improvement of this paper made by Drs. W.A. Laycock, W.J. McGinnies, and W.C. Leininger are appreciated. Support for this project was provided by the High Plains Grassland Research Station, USDA/ARS, and Colorado State University Agriculture Experiment Station through project 100 .

Manuscript accepted 24 December 1986.
}

what fraction of the total hoof surface was actually in contact with the ground. Thus, the loads assumed by Lull (1959), Dadkhah and Gifford (1980), and Busby and Gifford (1981) were too heavy, while those assumed by Frame (1971) were approximately correct.

The objectives of this study were to simulate trampling in a controlled environment so that plant material detached by hoof action alone could be accurately assessed, and to determine treading effects on soil bulk density and infiltration rates. Native shortgrass prairie sods were brought into the greenhouse and placed under 3 soil water regimes to determine if there were interactions between trampling and soil water potential on loss of aboveground forage. Trampling was applied to simulate either a continuous or a short-duration rotational grazing system to evaluate how different grazing systems might influence plant and soil variables.

\section{Materials and Methods}

A hydraulic soil-coring machine with a $14-\mathrm{cm}$ dia. sample tube similar to that described by Santos and Trlica (1978) was used to take $\mathbf{2 4 0}$ samples of native shortgrass prairie sod. Samples were taken from an Ascalon loam soil at the High Plains Grassland Research Station near Cheyenne, Wyo., after plant growth ceased in September, 1984. Vegetation was dominated by blue grama [Bouteloua gracilis (H.B.K.) Lag.] and western wheatgrass (Agropyron smithii Rydb.). Each sod core was placed carefully in a 15-cm dia. by $15-\mathrm{cm}$ deep can with as little disturbance as possible. Samples were transported to a greenhouse on the Colorado State University campus in Fort Collins. Each soil core was watered regularly to maintain favorable moisture levels (field capacity) during an initial growth period of 4 weeks in the greenhouse prior to trampling treatments.

The greenhouse was maintained at air-temperature of $20-30^{\circ} \mathrm{C}$, relative humidity of 20-50\%, a day-length of $14 \mathrm{~h}$, and maximum midday photosynthetically active radiation of about 400 to 1000 $\mu \mathrm{E} \bullet \mathrm{m}^{-2} \cdot \sec ^{-1}$. Soil water conditions within the sods were maintained at 3 levels. One-third of all sods were maintained at field capacity where water was applied throughout the 32-day experimental period at 2-to 3-day intervals to maintain leaf water potential of blue grama and western wheatgrass at about $-0.5 \mathrm{MPa}$ as measured with a pressure chamber (Scholander et al. 1965). The second water regime level was chosen to represent moderate water stress. Sods were not watered at the end of the 4-week initial growth period until soil water potential reached $<-10 \mathrm{MPa}$. Sods were then watered to field capacity (at approximately 6- to 7-day intervals) and the drying cycle repeated. The third soil water level was chosen to impose greater soil water stress on plants. Water was withheld from the sods until soil water potential reached $<-20$ $\mathrm{MPa}$. Sods were then watered to field capacity (at approximately 10-day intervals) and the cycle repeated. Soil water was monitored in the spatial center of the sods using thermocouple psychrometers similar to that described by Chung and Trlica (1980). All simulated trampling treatments were applied to each of the 3 soil water regime treatments.

An artificial hoof was cast of bronze from a mold of a hoof print of a steer. This hoof was somewhat similar to that used by Packer (1953) in his study of trampling. The area of the bottom of the cast was approximately $85 \mathrm{~cm}^{2}$. The artificial hoof was suspended from a long metal handle (Fig. 1). The handle was attached at one end to a pivot on a vertical stand; the hoof was suspended near the pivot. The end of the handle opposite the pivot was weighted to apply a static load on the hoof of $107 \mathrm{~kg}$ or $1.2 \mathrm{~kg} \mathrm{~cm}^{-2}$. Each sod core was placed under the hoof and the weighted handle dropped to apply 


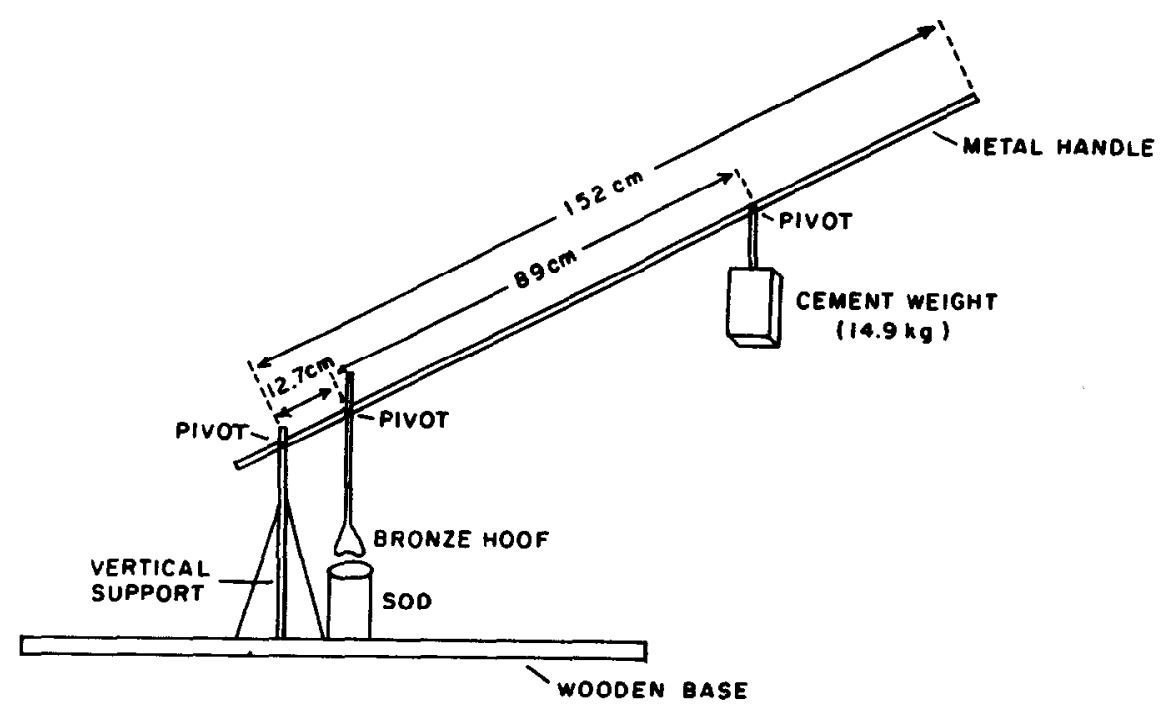

Fig. 1. Schematic diagram of the artificial hoof apparatus utilized in the trampling of shortgrass prairie sods.

the required pressure to the soil surface.

Sods were randomly assigned to each of 5 trampling intensities $\times 2$ grazing systems $\times 3$ water regimes $\times 4$ replications. The 5 trampling intensities were $32,16,8,4$, or 0 (control) footfalls/sod during the 32-day period. The simulated continuous grazing treatment was trampled once daily, once every other day once every fourth day, or once every eighth day, according to the intensity required. The simulated short-duration grazing treatment was trampled only during the last 4 days of the 32 -day period at $8,4,2$, or 1 footfalls/day. This resulted in the same number of total footfalls for the entire 32-day period under either grazing system at each of the trampling intensities.

The surface of the sods was vacuumed with a hand vacuum cleaner at the beginning of the treatment period and after each application of trampling. Material collected from the vacuum was sorted into live and dead categories, oven-dried at $60^{\circ} \mathrm{C}$, and weighed. The amount of material collected during the 32-day period was accumulated and summarized for each sod.

Aboveground biomass from all sods was clipped at the termination of the 32-day period, sorted into live and dead material, oven-dried at $60^{\circ} \mathrm{C}$ and weighed. The live and dead plant material collected was summed for each sod and the total aboveground biomass reported.

Soil bulk density and infiltration rates were measured at the end of the 32-day trampling period. One sod was randomly selected from each replication of each soil water regime $X$ grazing system combination within each simulated trampling level for each of the measurements. Soil bulk density was determined by taking a sample from the top $5 \mathrm{~cm}$ of the center of 1 sod, using the device described by Lutz (1947), and drying and weighing it. Infiltration rate was measured by insertion of a $5-\mathrm{cm}$ dia. graduated cylinder into the center of the second sod from 1 replication $X$ water regime $\times$ grazing system $\times$ trampling level combination. The graduated cyclinder was filled with water, and height of the water head was recorded at time intervals of $5,10,15,20,30,45,60,90$, and 120 minutes. Infiltration rate was calculated for the last 30 minutes ( 90 to 120 minutes) of the test period.

A randomized complete block design with factorial arrangements of treatments was used for data analysis. The 3 factors examined were trampling intensity (5), grazing system (2), and soil water regime (3). If an analysis of variance indicated significant differences $(P \leq 0.05)$ existed among treatment levels, then Duncan's new multiple range test was used to separate significant $(P \leq 0.05)$ means.

\section{Results}

Soil bulk density increased at the 2 greater trampling intensities (Table 1). In addition, bulk density was greater when the sods were trampled throughout the 32-day experimental period as compared with trampling that occurred during the last 4 days, which would simulate deferment followed by grazing under high stocking density. As expected, infiltration rate was slowed as trampling intensity increased (Table 1). The infiltration rate under the heaviest trampling intensity was less than one-half that under no trampling. Trampling throughout the 32-day experimental period had no more influence on the infiltration rate than did trampling only during the last 4 days of the 32-day period. Bulk density and water infiltration rate were not affected by the soil water regime of the sods. Water infiltration rate (1) was predicted by the equation I = $34.95 /($ footfalls $/$ day +1$)-6.64 ; r^{2}=0.24$.

Live shoot biomass increased with decreased water stress among the three soil water regimes (Table 2). Moderate and severe water stress regimes caused a drastic decrease in aboveground biomass production, but there was little difference in aboveground standing dead biomass among water stress regimes. Therefore, most of the differences in total shoot biomass among plants within the 3 soil water regimes were the result of greater living biomass under less severe soil water stress regimes.

Hoof action caused greater detachment of either living or dead shoot material when plants were under severe water stress (Table 2). About twice as much total plant material was detached when

Table 1. Soil bulk density and water infiltration rate as affected by intensity and timing of trampling.

\begin{tabular}{|c|c|c|c|c|c|c|c|}
\hline \multirow[b]{3}{*}{ Variable } & \multirow{2}{*}{\multicolumn{4}{|c|}{$\begin{array}{l}\text { Trampling intensity } \\
\text { (No. footfalls/sod) }\end{array}$}} & \multirow{3}{*}{$\frac{\text { Control }}{\text { No trampling }}$} & \multicolumn{2}{|c|}{ Time of trampling } \\
\hline & & & & & & \multirow{2}{*}{$\begin{array}{l}\text { Throughout } \\
32 \text { days }\end{array}$} & \multirow{2}{*}{$\begin{array}{l}\text { During last } \\
4 \text { days }\end{array}$} \\
\hline & 32 & 16 & 8 & 4 & & & \\
\hline Bulk density $\left(\mathrm{g} / \mathrm{cm}^{3}\right)$ & $1.20 \mathrm{ab}$ & $1.25 \mathrm{a}$ & $1.16 \mathrm{~b}$ & $1.18 \mathrm{~b}$ & $1.17 \mathrm{bX}$ & $1.22 \mathrm{Y}$ & $1.17 X$ \\
\hline Infiltration rate $(\mathrm{cm} / \mathrm{hr})$ & $12.9 \mathrm{c}$ & $15.0 \mathrm{bc}$ & $18.6 \mathrm{~b}$ & $25.1 \mathrm{a}$ & $29.9 \mathrm{aY}$ & $16.8 X$ & $19.0 \mathrm{X}$ \\
\hline
\end{tabular}

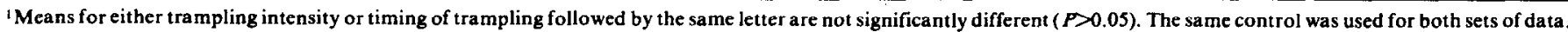


Table 2. Shoot biomass and weight of vegetation detached by hoof action as affected by soil water regime.

\begin{tabular}{lccc}
\hline & \multicolumn{3}{c}{ Soil water regime } \\
\cline { 2 - 4 } Variable & $\begin{array}{c}\text { Field capacity } \\
(-0.1 \mathrm{MPa})\end{array}$ & $\begin{array}{c}\text { Moderate stress } \\
(0 \text { to }-1.0 \mathrm{MPa})\end{array}$ & $\begin{array}{c}\text { Severe stress } \\
(0 \text { to }-2.0 \mathrm{MPa})\end{array}$ \\
\hline Shoot biomass $\left(\mathrm{g} / \mathrm{m}^{2}\right)$ & $138 \mathrm{a}$ & $101 \mathrm{~b}$ & $54 \mathrm{c}$ \\
Live & $98 \mathrm{a}$ & $85 \mathrm{~b}$ & $83 \mathrm{~b}$ \\
Dead & $236 \mathrm{a}$ & $186 \mathrm{~b}$ & $137 \mathrm{c}$ \\
Total & & & \\
Detached vegetation $\left(\mathrm{g} / \mathrm{m}^{2}\right)$ & $5 \mathrm{~b}$ & $5 \mathrm{~b}$ & $11 \mathrm{a}$ \\
Live & $19 \mathrm{c}$ & $23 \mathrm{~b}$ & $40 \mathrm{a}$ \\
Dead & $24 \mathrm{~b}$ & $28 \mathrm{~b}$ & $51 \mathrm{a}$ \\
Total & & & \\
\hline
\end{tabular}

IMeans in a row followed by the same letter are not significantly different $(P>0.05)$.

plants were under severe water stress. Evidently, both live and dead leaves and culms were more elastic when plants had not been subjected to severe water stress.

Standing crop of shoot biomass generally decreased as the trampling intensity increased (Table 3). This was evident in both live and dead shoot biomass categories. Standing crop of live shoot biomass was lower if the same amount of trampling was done throughout the 32-day period, rather than during the last 4 days.

The weight of living or dead standing crop of shoots that were detached by hoof action increased at the heavier trampling intensities (Table 3). Trampling throughout the 32-day period resulted in more dead shoot biomass being detached than live shoot biomass when compared with trampling only during the last 4 days of the trial.

\section{Discussion and Conclusions}

Water infiltration rates reported here should not be considered as accurate estimates of infiltration under field conditions, but only as indications of the relative impact of the treatments on infiltration. Equilibrium infiltration rates for undisturbed sites from our field experiment, where our sod cores were taken, averaged $8.9 \mathrm{~cm}$ $\mathrm{hr}^{-1}$ as measured by double-ring infiltrometer (Abdel-Magid et al. 1987). Maximum equilibrium infiltration rate under a rainfall simulator was $5.1 \mathrm{~cm} \mathrm{hr}^{-1}$ on the same soil series with similar vegetation (Rauzi and Smith 1973). Ueckert et al. (1978) found that infiltration estimates using an infiltrometer averaged $41 \%$ higher than those using similated rainfall. Branson et al. (1981) concluded that the ring infiltrometer provided a poor estimate of infiltration under natural rainfall, but comparative differences could be obtained with this method. The small size of the sods in this greenhouse study made it impractical to use a double-ring infiltrometer; lateral movement of water was considerable and inflated estimates of infiltration rates.
Soil water regimes had little effect on soil bulk density and water infiltration rate, as measured in this experiment. Bulk density increased slightly and infiltration rate declined sharply under severe levels of trampling. This may have resulted from a decrease in soil macropore space with an increase in micropore space. However, the 2 heavy levels of trampling would rarely be experienced under field conditions. Maximum distance travelled by steers observed in another experiment (Abdel-Magid et al. 1987) was $4.8 \mathrm{~km} /$ day under continuous grazing stocked at 60 steer days / ha; this was equivalent to $2,304,000$ footfalls / ha. If the hoofprint size averaged $85 \mathrm{~cm}^{2}$, total area trampled would be 19,584 $\mathrm{m}^{2} /$ ha or $22 \%$ of the total area of the pasture. Steers travelled only $1.6 \mathrm{~km}$ per day under short duration grazing stocked at the same rate, so they trampled only about $7 \%$ of the pasture area (AbdelMagid et al. 1987). No differences were found in water infiltration rates among grazing systems or stocking rates in the field study, which supported results of this greenhouse trampling experiment.

Trampling throughout the 32-day treatment period had a greater effect on bulk density than did trampling during the last 4 days of the treatment period. Although Savory and Parsons (1980) implied that hoof action under short-duration grazing might have desirable benefits for soil characteristics, we found similar infiltration rates under the simulated continuous and short-duration grazing systems in this greenhouse experiment.

The influence of soil water regime on shoot biomass production followed the same trend reported by Levitt (1980); aboveground production was reduced with increasing water stress. It should be noted, however, that even under severe stress of $-2.0 \mathrm{MPa}$ soil water potential, both blue grama and western wheatgrass produced aboveground biomass after a drying cycle.

Trampling intensity (number of footfalls/ sod) was more influential in causing a reduction of shoot biomass and detachment of either living or dead shoot material than was the timing of this trampling. The 32,16 , and 8 footfalls/sod during the 32 -day period were considered severe trampling and would rarely be experienced under field conditions. Under a moderate level of trampling (4 footfalls/sod), trampling was less effective in reducing shoot production or in detaching living or dead vegetation. Dead vegetation, however, was more easily removed by hoof action than was living vegetation. This was to be expected, as the material would not be as elastic and would shatter upon hoof impact. Severe water stress also made the plant material more brittle.

A comparison of total shoot biomass with the total amount of material detached by trampling showed that 15 to $25 \%$ of the plant material was actually detached by the hoof action. This could represent a significant loss of forage as a result of animal activity. However, under conditions of moderate trampling, as under our trampling intensity of 4-footfalls/sod, only approximately $5 \%$ of the living biomass was lost, which is much less than the losses reported by Laycock et al. (1972) and Laycock and Harniss (1974) in a tall forb vegetation type, but consistent with losses of Quinn

Table 3. Shoot biomass and weight of vegetation detached by hoof action as affected by intensity and timing of trampling.

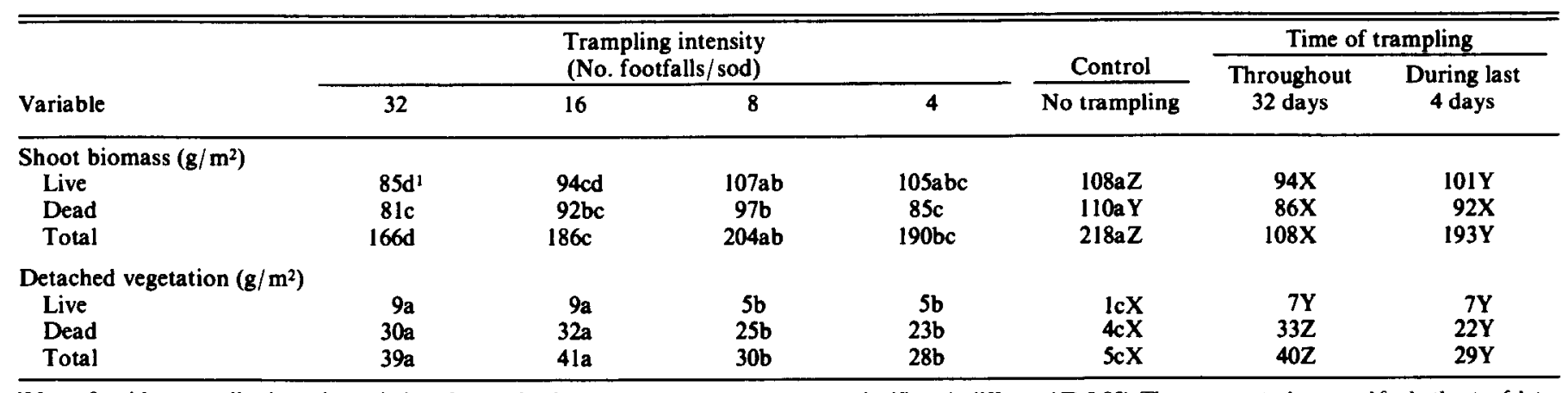

IMeans for either trampling intensity or timing of trampling followed by the same letter are not significantly different $(P>0.05)$. The same control was used for both sets of data. 
and Hervey (1970) on a similar shortgrass vegetation type.

Steers probably graze less efficiently in a continuous grazing system because they search for a few preferred plants. The time and energy spent in search are probably reduced in a short-duration grazing system because animals are confined to a smaller portion of the whole pasture. Therefore, they walk less (Abdel-Magid et al. 1987) and trample less vegetation in the short-duration grazing system. Regrowth of vegetation in this system is elastic and not as vulnerable to detachment by hoof impact as compared with vegetation in the continuous grazing system. Ungrazed vegetation within the continuous grazing system should be more mature and, consequently, brittle and easily detached.

The greater amount of vegetation detached under the continuous grazing system, as compared with the short-duration grazing system (Table 3), did not agree with the conclusions of Holechek (1980). He indicated that short-duration grazing should reduce excessive accumulation of standing dead vegetation and mulch. Our study indicated little difference could be expected for the amount of living plant material detached by trampling within either of the grazing systems, but live shoot biomass was greater under the short-duration simulated grazing system.

\section{Literature Cited}

Abdel-Magid, A.H., G.E. Schuman, and R.H. Hart. 1987. Soil bulk density and water infiltration rates as affected by three grazing systems. J. Range Manage. 40:307-310.

Balph, D.F., and J.C. Malecheck. 1985. Cattle trampling of crested wheatgrass under short-duration grazing. J. Range Manage. 38:226-227.

Branson, F.A., G.F. Gifford, K.G. Renard, and R.F. Hadley. 1981. Rangeland hydrology, 2nd ed. Kendall/Hunt Pub. Co., Dubuque, Iowa.

Brown, K.R., and D.S. Evans. 1973. Animal treading, a review of the work of the late D.B. Edmond. New Zeal. J. Exp. Agr. 1:217-226.

Busby, F.E., and G.F. Gifford. 1981. Effects of livestock grazing on infiltration and erosion rates measured on chained and unchained pinyonjuniper sites in southeastern Utah. J. Range Manage. 34:400-405.

Chung, Hsu-Ho, and M.J. Trlica. 1980. ${ }^{14} \mathrm{C}$ distribution and utilization in blue grama as affected by temperature, water potential and defoliation regimes. Oecologia 47:190-195.
Dadkhah, M., and G.F. Gifford. 1980. Influence of vegetation, rock cover and trampling on infiltration rates and sediment production. Water Resources Bull. 16:979-986.

Frame, J. 1971. Fundamentals of grassland management. Pt. 10. The grazing animal. Scottish Agr. 50:28-44.

Holechek, J. 1980. Livestock grazing impacts on rangeland ecosystem. J. Soil Water Conserv. 35:162-164.

Laycock, W.A., H. Buchanan, and W.E. Krueger. 1972. Three methods of determining diet, utilization, and trampling damage on sheep ranges. J. Range Manage. 25:352-356.

Laycock, W.A., and R.O. Harniss. 1974. Trampling damage on native forb grass ranges grazed by sheep and cattle. p. 349-354. In: Sectional papers: Grasslands Utilization, XII Internat. Grassl. Congr., Moscow.

Levitt, J. 1980 . Responses of plants to environmental stresses. Vol. II. Water, radiation, salt, and other stresses. 2nd Ed. Academic Press, New York. 607 p.

Lewis, C.E. 1980. Simulated cattle injury to planted slash pine: combination of defoliation, browsing and trampling. J. Range Manage. 33:340-345.

Lull, H.W. 1959. Soil compaction on forest and rangelands. USDA Forest Serv. Misc. Pub. No. 768.

Lutz, J.R. 1947. Apparatus for collecting undisturbed soil samples. Soil Sci. 64:399-401.

Pucker, P.E. 1953. Effects of trampling disturbance on watershed condition, runoff, and erosion. J. Forestry 51:28-31.

Pearson, H.A. 1974. Cattle forage evaluated by fistula technique on southern forest grasslands. p. 548-551. In: Sectional papers: Grasslands Utilization, XII Internat. Grassl. Congr., Moscow.

Pearson, H.A. 1975. Herbage disappearance and grazing capacity determination of southern pine bluestem range. J. Range Manage. 28:71-73.

Quinn, J.A., and D.F. Hervey. 1970. Trampling losses and travel by cattle on sandhill range. J. Range Manage. 23:50-55.

Santos, G.L., and M.J. Trlica. 1978. Clipping effects on production and carbohydrate reserves of blue grama and western wheatgrass. p. 384-386. In: D.N. Hyder (ed.) Proc. 1st Int. Rangeland Congr., SRM, Denver, Colo.

Savory, A., and S.D. Parsons. 1980. The Savory grazing method. Rangelands 2:234-237.

Scholander, P.F., H.T. Hamel, E.D. Bradstreet, and E.A. Hemmingsen. 1965. Sap pressure in vascular plants. Science 148:339-346.

Ueckert, D.N., T.L. Whigham, and B.M. Spears. 1978. Effect of burning on infiltration, sediment, and other soil properties in a mesquitetobosagrass community. J. Range Manage. 31:420-425. 